\title{
Diversity of Cryptosporidium spp. in wild rodents from the Canary Islands, Spain
}

\author{
Katherine García-Livia ${ }^{1,2}$, Aarón Martín-Alonso ${ }^{1}$ and Pilar Foronda ${ }^{1,2^{*}}$
}

\begin{abstract}
Background: Cryptosporidium spp. are worldwide protozoan parasites which include species that can lead to cryptosporidiosis in humans. Different animal species can serve as reservoirs and sources of dissemination of the disease, such as rodent species due their potential in transmitting zoonotic pathogens to humans and other animals. In the Canary Islands (Spain), Cryptosporidium parvum and Cryptosporidium hominis have been identified in patients with diarrhea. However, the occurrence of Cryptosporidium spp. in possible reservoirs in this archipelago remains unclear. Considering the zoonotic potential of these protozoans, the aim of the present study was to determine the presence of Cryptosporidium spp. in peridomestic wild rodents and the possible role of these mammals as a source of transmission of these protozoans in Canary Islands.
\end{abstract}

Methods: A total of 179 rodents belonging to Rattus rattus and Mus musculus domesticus from four Canary Islands, La Palma, El Hierro, Tenerife and Lanzarote, were analyzed. Feces were screened for Cryptosporidium spp. by nested PCR of the 185 ribosomal RNA fragment and the sequences used for phylogenetic analyses.

Results: Cryptosporidium spp. were found widely distributed with an overall prevalence of $12.30 \%$ in rodents (13.86\% for $R$. rattus and $10.25 \%$ for M. m. domesticus). The overall prevalence by island was $19.60 \%$ for Tenerife, $7.14 \%$ for La Palma, 5.71\% for El Hierro and 0\% for Lanzarote. Cryptosporidium tyzzeri, Cryptosporidium meleagridis, Cryptosporidium muris and Cryptosporidium sp. rat genotype I and II/III were successfully identified, in addition to two unidentified Cryptosporidium genotypes.

Conclusions: This study contributes to the knowledge of the biodiversity and distribution of Cryptosporidium spp. in wild rodents from the Canary Islands, highlighting the presence of three zoonotic species, C. tyzzeri, C. meleagridis and C. muris, being the first detection of these three species in wild rodents in the Canary Islands and the first report of C. meleagridis in $R$. rattus. Given the results obtained in our study, future studies in non-sampled areas are required to better understand the epidemiology of these protozoans in wild rodents in the archipelago.

Keywords: Cryptosporidium tyzzeri, Cryptosporidium meleagridis, Cryptosporidium muris, Zoonoses, Wild rodents, Canary Islands

\footnotetext{
*Correspondence: pforonda@ull.edu.es

${ }^{1}$ Instituto Universitario de Enfermedades Tropicales y Salud Pública de

Canarias, Universidad de La Laguna, San Cristobal de La Laguna, Canary Islands, Spain

Full list of author information is available at the end of the article
}

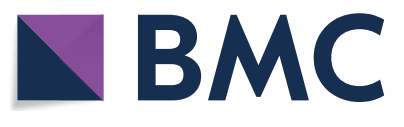

(c) The Author(s) 2020. This article is licensed under a Creative Commons Attribution 4.0 International License, which permits use, sharing, adaptation, distribution and reproduction in any medium or format, as long as you give appropriate credit to the original author(s) and the source, provide a link to the Creative Commons licence, and indicate if changes were made. The images or other third party material in this article are included in the article's Creative Commons licence, unless indicated otherwise in a credit line to the material. If material is not included in the article's Creative Commons licence and your intended use is not permitted by statutory regulation or exceeds the permitted use, you will need to obtain permission directly from the copyright holder. To view a copy of this licence, visit http://creativecommons.org/licenses/by/4.0/. The Creative Commons Public Domain Dedication waiver (http://creativecommons.org/publicdomain/zero/1.0/) applies to the data made available in this article, unless otherwise stated in a credit line to the data. 


\section{Background}

Cryptosporidium spp. are worldwide protozoan parasites that can be found in the environment and parasitizing humans and an extensive group of wild animal species [1]. They are considered common causes of water-borne and food-borne outbreaks and have been identified in different groups of domestic and wild animal species such as pets, livestock and rodents, among others [2-6]. Cryptosporidium species are resistant to various environmental conditions and are opportunistic pathogens responsible of cryptosporidiosis, a gastrointestinal disease with a wide spectrum of clinical symptoms, where the severity and persistence of the infection are dependent on host factors and parasite characteristics [7].

In humans, Cryptosporidium spp. can cause cryptosporidiosis, a disease with mild to severe signs and symptoms depending on parasite-related factors, site of infection and nutritional and immune status of the host [8]. In healthy individuals, cryptosporidiosis is a self-limiting diarrhea and may also result in chronic or life-threatening diarrhea in individuals with a compromised immune system [8]. Cryptosporidium parvum and Cryptosporidium hominis are the most frequent species related to cryptosporidiosis and the most common species involved in water-borne epidemics $[9,10]$. Cryptosporidium hominis is responsible for approximately $80 \%$ of human cases in European countries [11], and the main species causing illness in childhood (see [8]).

More than 40 Cryptosporidium species have been described as valid worldwide [12-14], and around 20 species and genotypes have been reported in humans, such as Cryptosporidium meleagridis, Cryptosporidium felis, Cryptosporidium canis, Cryptosporidium ubiquitum, Cryptosporidium cuniculus, Cryptosporidium viatorum, Cryptosporidium muris, Cryptosporidium andersoni, Cryptosporidium suis, Cryptosporidium bovis, Cryptosporidium xiaoi, Cryptosporidium erinacei, Cryptosporidium fayeri, Cryptosporidium scrofarum, Cryptosporidium tyzzeri, chipmunk genotype I, horse genotype, skunk genotype and mink genotype $[12,15]$.

Wild mammals, especially rodents, can coexist in anthropogenic environments and pose a risk to public health as they are reservoirs of viruses, bacteria and parasites [16], many of them with zoonotic importance, including some Cryptosporidium species, among others [17]. There are hosts of a large number of Cryptosporidium species and genotypes that have been diagnosed in sporadic human cases including C. parvum, C. muris, C. ubiquitum, C. meleagridis, C. scrofarum, Cryptosporidium proliferans, Cryptosporidium occultus, $C$. viatorum, C. canis, Cryptosporidium wrairi, C. tyzzeri, Cryptosporidium rubeyi, C. andersoni, C. hominis, C. suis and rat genotypes I-IV, mouse genotypes II and III, the Naruko genotype, ferret genotype, chipmunk genotypes, hamster genotype, deer mouse genotypes I-IV, vole genotype, bear genotype, muskrat genotypes I and II and ground squirrel genotypes I-III [18-20]. Furthermore, recently some new species have been described in different rodent species, among them Cryptosporidium alticolis and Cryptosporidium microti in wild-caught common voles [21], Cryptosporidium ditrichi and Cryptosporidium apodemi in Apodemus spp. mice [22, 23]. Among these recently discovered species, $C$. ditrichi has shown a certain zoonotic potential since it has been newly reported infecting three patients in Sweden [24].

Rodents adapt easily to a wide variety of habitats in abundant populations being present in more than $80 \%$ of the islands worldwide [25]. The Canary Islands, an archipelago composed by eight islands and islets, contain a marked vegetation and the weather is strongly influenced by humid trade winds producing a marked vegetations belts [26]; this favors the existence of many types of ecosystems where rodents can proliferate and increase their population easily.

It has been shown that the bioclimatic conditions affect the distributions of some pathogens in the Canary Islands [27]. The available data about the presence of Cryptosporidium species in this archipelago are based on human feces [28], wastewater samples [29-31] and birds, concretely in pigeons [30, 32], C. hominis and C. parvum being the frequently detected species.

Studies related to Cryptosporidium spp. in wild mammals as possible reservoirs in the Canary Islands are scarce. In case of wild rodents, the study carried out by Feliu et al. [33] was the first to provide data about the parasite fauna of both murine species studied, Rattus rattus and Mus musculus domesticus, in El Hierro Island, and revealed an overall prevalence of $C$. parvum of $48.6 \%$.

Therefore, the aim of the present study was to analyze the distribution, prevalence and identity of Cryptosporidium species present in wild rodents from the Canary Islands, and analyze the role of wild rodents in the maintenance and transmission of Cryptosporidium spp. in this archipelago, with special attention to zoonotic species.

\section{Methods}

\section{Sample collection}

The Canary Islands (Spain) are located off NW Africa, between $13^{\circ} 23^{\prime}$ and $18^{\circ} 8^{\prime} \mathrm{W}$ and $27^{\circ} 37^{\prime}$ and $29^{\circ} 24^{\prime}$ N. From a multidisciplinary study carried out in this archipelago, a total of 179 wild rodents of the species $R$. rattus $(n=101)$ and $M . m$. domesticus $(n=78)$, from El Hierro $(n=35)$, La Palma $(n=14)$, Tenerife $(n=97)$ and Lanzarote $(n=33)$, were selected and analyzed for the presence of Cryptosporidium spp. (Fig. 1). A 


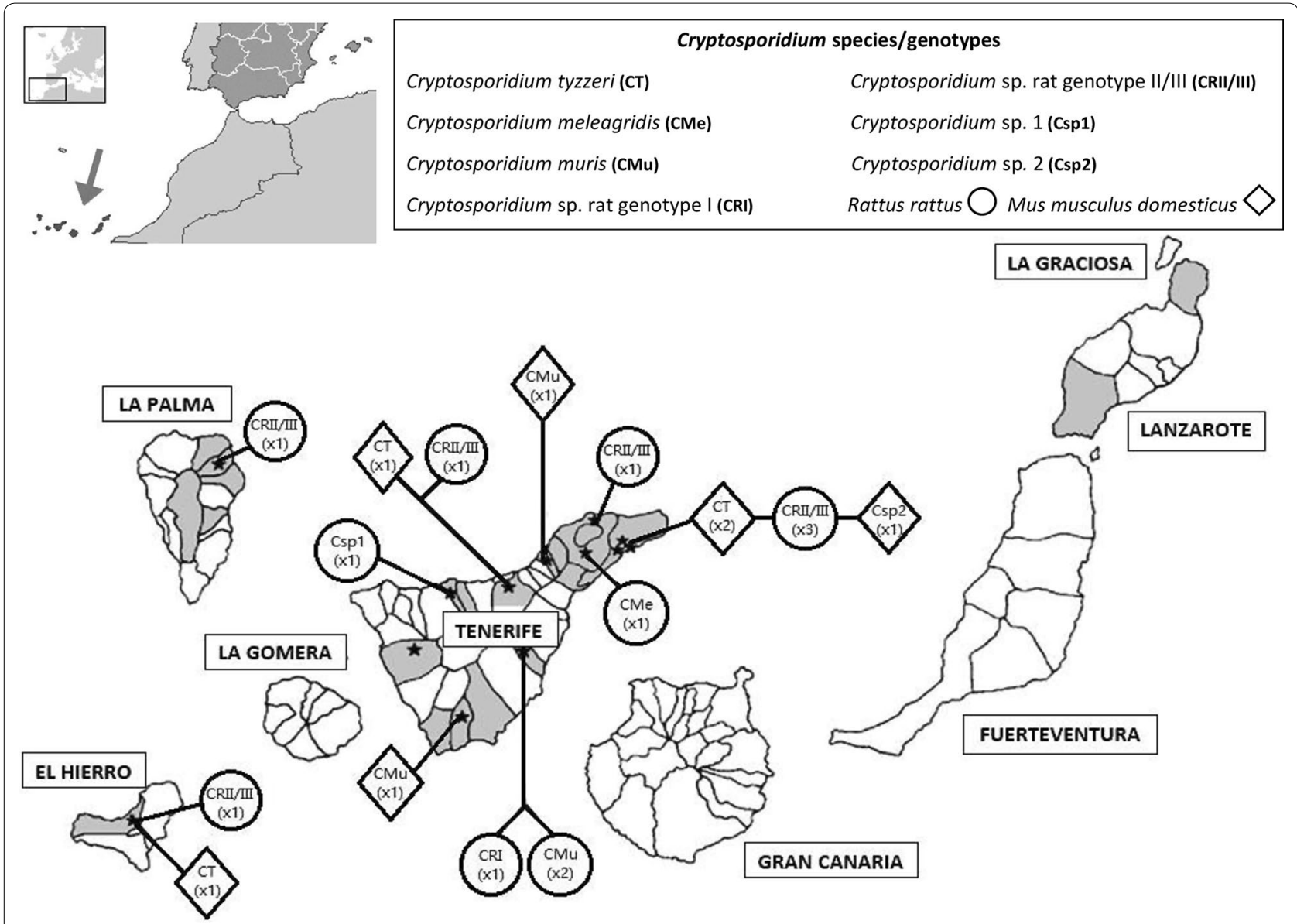

Fig. 1 Location of the Canary Islands and the geographical distribution of rodents sampling locations analyzed in the present study (gray). Black stars represent the presence of Cryptosporidium spp. in wild rodents. An indication code for species, genotypes and hosts is provided at the top of the panel

portion of fecal samples from the rectum of each animal has been preserved in $2.5 \%$ potassium dichromate and examined. Fecal oocysts were concentrated using a modification of Richie's formaldehyde-ether method [34], in which the formaldehyde-ether was replaced by ethyl acetate, since it presents less distortion in the structures [35].

\section{DNA isolation}

Total DNA of the concentrated feces samples was extracted following the manufacturer's instructions with the commercial FastDNA ${ }^{\circledR}$ Spin Kit for Soil (MP Biomedicals, Solon, OH, USA) using the homogenizer FastPrep-24 5 G (MP Biomedicals) as oocyst disruptor. Quantity and quality of the extracted DNA were determined with the spectrophotometer Nanodrop ND-1000 (Thermo Fisher Scientific, Wilmington, DE, USA). DNA was stored at $-20^{\circ} \mathrm{C}$ until further processing.

\section{PCR amplification}

Cryptosporidium spp. were detected by nested PCR amplification of an $830 \mathrm{bp}$ region of the $18 \mathrm{~S}$ ribosomal RNA fragment using the primers SSU-F1 and SSU-R1 for the primary PCR, and SSU-F2 and SSU-R2 for the secondary PCR [36]. The set-up of the PCR reactions was carried out following [37]. The reaction mixture for all pairs of primers contained $0.625 \mathrm{U}$ Taq DNA polymerase, $0.4 \mathrm{Taq}$ of each primer, $200 \mu \mathrm{M}$ each dNTPs, 2 $\mathrm{mM} \mathrm{MgCl} 2,1 \times$ buffer $\left(\mathrm{Mg}^{2+}\right.$ free), $2 \mu$ of DNA template and $\mathrm{H}_{2} \mathrm{O}$ to a total volume of $25 \mu \mathrm{l}$. The cycling conditions were initial denaturation of $95^{\circ} \mathrm{C}$ for 5 min followed by 35 cycles $94{ }^{\circ} \mathrm{C}$ for $45 \mathrm{~s}, 45 \mathrm{~s}$ at suitable temperature $\left(55^{\circ} \mathrm{C}\right.$ for the primary PCR and $58{ }^{\circ} \mathrm{C}$ for the secondary PCR), and $1 \mathrm{~min}$ at $72{ }^{\circ} \mathrm{C}$, followed by a final extension step at $72{ }^{\circ} \mathrm{C}$ for $10 \mathrm{~min}$. Both positive and negative controls were included in each test using Cryptosporidium sp. rat genotype III as a positive control. All amplicons 
were resolved on 1.5\% agarose gels and purified using the EZNA Gel Extraction Kit (Omega Bio-Tek, Norcross, GA, USA).

\section{Sequencing and phylogenetic analyses}

Purified products were sequenced in SEGAI (University of La Laguna sequencing services, La Laguna, Tenerife, Spain) and Macrogen Inc. (Madrid, Spain). Nucleotide sequences obtained for each amplified region were edited with the MEGA X program [38] and subsequently aligned with the ClustalW program included in MEGA $\mathrm{X}$. Minor corrections, to increase the aligned sequence similarity and improve the inferences on any positional homology, were then made by hand. A BLAST search was carried out in order to elucidate any homologies or similarities of the nucleotide variants obtained with the sequences previously published in the GenBank database. The molecular identification was achieved by phylogenetic analysis through the Neighbor-Joining distance method [39] with at least 1000 bootstrap replications. For the phylogenetic analyses, the nucleotide sequences obtained in this work and other Cryptosporidium spp. sequences obtained from GenBank were aligned, Toxoplasma gondii was used as the outgroup.

Chi-square test was used to determine differences in the prevalence of Cryptosporidium spp. between the rodent species, and $P$-values below 0.05 were considered statistically significant.

\section{Results}

The overall prevalence of Cryptosporidium spp. in rodents from the Canary Islands was $12.30 \%$, since amplification of the $18 \mathrm{~S}$ rRNA gene fragment of Cryptosporidium spp. was successful in 22 out of 179 individuals tested. Most of the positive results were obtained on the island of Tenerife (19.60\%) followed by La Palma (7.14\%) and El Hierro (5.71\%). All fecal samples tested for Lanzarote Island were negative $(n=33)$ (Table 1$)$.

Considering the rodent species analyzed, both were found infected with Cryptosporidium spp., and no significant differences were found in relation to overall prevalence. The overall prevalence of infection with Cryptosporidium spp. in $R$. rattus was $13.86 \%$, found in three of the four sampled islands (18.18\% in Tenerife, 11.11\% in La Palma and 7.14\% in El Hierro). Considering $M$. m. domesticus, the overall prevalence was $10.25 \%$. Mice parasitized by Cryptosporidium spp. were only found in Tenerife (22.60\%) and El Hierro (4.76\%) islands.

A total of 20 PCR-positive samples from La Palma, El Hierro and Tenerife islands were successfully sequenced. We decided to exclude one Cryptosporidium spp.-positive sample from the data used for genetic analyses due to an insufficient amount of DNA. The obtained sequences generated in this study have been submitted to the GenBank database under the accession numbers MN599007MN599026 and MN783636-MN783642.

The Neighbor-Joining analysis of various Cryptosporidium species/genotypes and the 19 isolates from wild rodents from the Canary Islands are shown in Fig. 2. Phylogenetic analysis showed the presence of 7 Cryptosporidium species and genotypes (Fig. 2, Table 1). Cryptosporidium tyzzeri $(n=4), C$. meleagridis $(n=1)$, C. muris $(n=4)$, Cryptosporidium sp. rat genotype I $(n=1)$ and Cryptosporidium sp. rat genotype II/III $(n=7)$ were identified. Furthermore, two Cryptosporidium genotypes with uncertain species status were found; the first, Cryptosporidium sp. 1 (isolate CR 72 from $R$. rattus), clustered with Cryptosporidium spp. sequences obtained from

Table 1 Occurrence of Cryptosporidium species/genotypes in wild rodents in the Canary Islands, Spain

\begin{tabular}{|c|c|c|c|c|}
\hline Island & $\begin{array}{l}\text { Rattus rattus } \\
\mathrm{n} / \mathrm{N}(\mathrm{P} \%)\end{array}$ & $\begin{array}{l}\text { Mus musculus domesticus } \\
\mathrm{n} / \mathrm{N}(\mathrm{P} \%)\end{array}$ & $\begin{array}{l}\text { Total } \\
n / N(P \%)\end{array}$ & Species/Genotype \\
\hline \multirow[t]{2}{*}{ El Hierro } & \multirow[t]{2}{*}{$1 / 14(7.14)$} & \multirow[t]{2}{*}{$1 / 21(4.76)$} & \multirow[t]{2}{*}{$2 / 35(5.71)$} & Cryptosporidium tyzzeri (M) \\
\hline & & & & Cryptosporidium sp. rat genotype $\|/ I\|(R)$ \\
\hline La Palma & $1 / 9(11.11)$ & $0 / 5(0)$ & $1 / 14(7.14)$ & Cryptosporidium sp. rat genotype $\|/\| \|(R)$ \\
\hline \multirow[t]{7}{*}{ Tenerife } & \multirow[t]{7}{*}{$12 / 66(18.18)$} & \multirow[t]{7}{*}{$7 / 31(22.60)$} & \multirow[t]{7}{*}{ 19/97 (19.60) } & Cryptosporidium muris (R, M) \\
\hline & & & & Cryptosporidium tyzzeri (M) \\
\hline & & & & Cryptosporidium. meleagridis (R) \\
\hline & & & & Cryptosporidium sp. rat genotype I (R) \\
\hline & & & & Cryptosporidium sp. rat genotype $\| / / I I(R)$ \\
\hline & & & & Cryptosporidium sp. 1 (R) \\
\hline & & & & Cryptosporidium sp. 2 (M) \\
\hline Lanzarote & $0 / 12(0)$ & $0 / 21(0)$ & $0 / 33(0)$ & \\
\hline Total & 14/101 (13.86) & $8 / 78(10.25)$ & $22 / 179(12.30)$ & \\
\hline
\end{tabular}

Abbreviations: $n / N$ (P\%), no. of positive animals for Cryptosporidium spp./no. of samples analyzed (prevalence \%); R, Rattus rattus; M, Mus musculus domesticus 


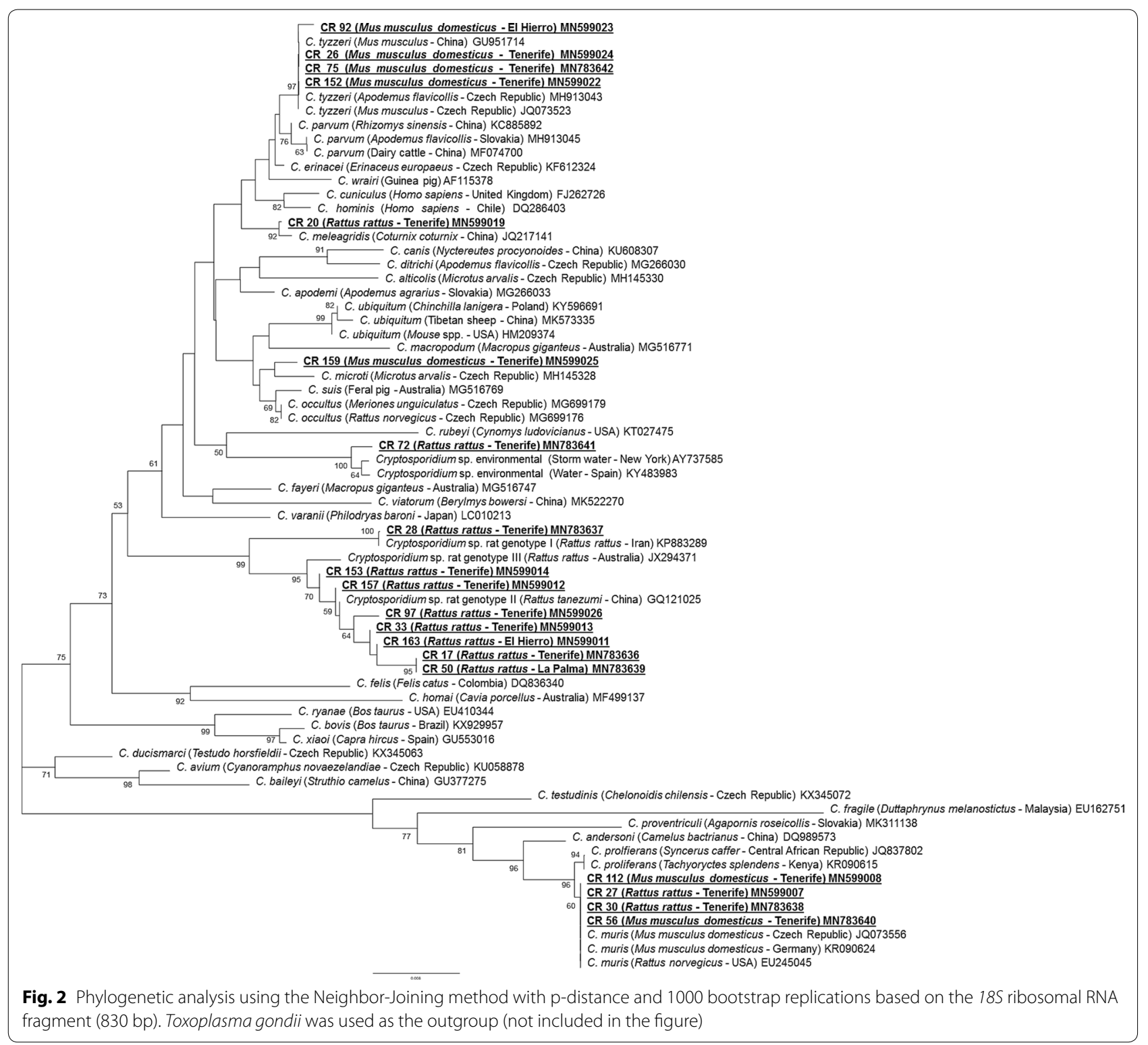

environmental samples in Spain (GenBank: KY483983) and in New York (GenBank: AY737585), and the other unnamed species, Cryptosporidium sp. 2 (isolate CR 159 from M. m. domesticus), grouped together with C. microti (GenBank: MH145328), and also clustered together with the species C. suis (GenBank: MG516769) and C. occultus (GenBank: MG699176 and MG699179).

Cryptosporidium tyzzeri was confirmed in 4 samples of M. m. domesticus, one from El Hierro island (isolate CR 92) and 3 from Tenerife island (isolates CR 26, CR 75 and CR 152). Another sequence obtained from $R$. rattus in Tenerife (isolate CR 20) clustered with C. meleagridis. Furthermore, phylogenetic analysis revealed that 8 sequences were broadly grouped in the clade containing rat genotypes I, II and III. One sequence (isolate CR 28 from Tenerife) clustered with rat genotype I in a separate clade, and the other 7 sequences (isolates CR 17, CR 33, CR 97, CR 153, CR 157 from Tenerife, CR 50 from La Palma and CR 163 from El Hierro) clustered with rat genotype II and rat genotype III. Moreover, 4 samples from Tenerife, 2 isolates from $R$. rattus (CR 27 and CR 30) and 2 isolates from M. m. domesticus (CR 56 and CR 112) were clustered with $C$. muris in the same clade.

\section{Discussion}

Anthropogenic environmental changes, together with globalization effects can lead to an increase of zoonotic diseases whose origin is mostly wildlife [40, 41]. An 
example is cryptosporidiosis, considered one of the most common causes of diarrhea worldwide [42], in which wild rodents, due to their high reproductive capacity, zoonotic potential and close association with humans, favor the transmission by spreading through their feces the causative agents. This is considered a risk to both public and veterinary health as these animals could spread the disease to new environments and hosts [43, 44].

Prevalence rates of Cryptosporidium spp. infections in rodent species could be highly variable worldwide. In this sense, prevalence values are reported ranging between $8.0-31.4 \%$ and $2.1-63.0 \%$ in mice and rats, respectively $[18,19,45,46]$. In our study, the overall prevalence of Cryptosporidium spp. in the Canary Islands was $10.25 \%$ in mice and $13.86 \%$ in rats. It is important to note that the prevalence values for Cryptosporidium spp. can fluctuate due to factors such as the host species analyzed, sample areas, bioclimatic conditions and methods applied [46].

In the Canary Islands, a total of 7 Cryptosporidium species/genotypes were detected in wild rodents in this study, demonstrating a high diversity of these protozoans in the archipelago. Previous studies carried out in this region have identified $C$. parvum and $C$. hominis in hospitalized patients with diarrhea [28], and C. hominis was also detected in other samples such as wastewater and pigeons feces [30].

In the present study, C. tyzzeri, C. meleagridis and C. muris were found in wild rodents, and considering their zoonotic potential, these species could be involved in cases of human diarrhea without specific identification, since the specific identification is not carried out at the Canary Hospitals.

Cryptosporidium tyzzeri, redescribed from Cryptosporidium sp. mouse genotype I [47], mostly infects domestic mice and small rodents, and it has been found in several non-specific hosts such as the lesser panda, black leopards, voles, snakes and horses, among others [48-51]. Cryptosporidium tyzzeri has also been recently reported for the first time in Apodemus spp., suggesting this murine species as a minor host due to the low prevalence obtained [23]. In humans, a severe cryptosporidiosis caused by a coinfection of C. tyzzeri and C. parvum has been reported in healthy young individual, demonstrating that the transmission of Cryptosporidium spp. from synanthropic rodents to humans can occur, suggesting the zoonotic potential of C. tyzzeri [52].

Cryptosporidium meleagridis is a common cause of cryptosporidiosis in avian hosts. Until now, studies carried out in Japan, New York and Malaysia, have reported the presence of $C$. meleagridis in Rattus norvegicus (brown rat), Peromyscus sp. (deer mouse), and in one unidentified rodent species [53-55]. Therefore, our study is the fourth report of $C$. meleagridis in rodents, and also the first report of $C$. meleagridis in $R$. rattus. As Tan et al. [55] suggest, this could indicate a possible role of rodents in mechanical transmission of this pathogen. Cryptosporidium meleagridis is considered to be the third most common species involved in human cryptosporidiosis after C. hominis and C. parvum [56]. It has shown that $C$. meleagridis is responsible for $10-20 \%$ of human cryptosporidiosis in some countries such as Thailand and Peru $[57,58]$; zoonotic transmission in Sweden has also been reported [59]. In Spain, only one case of cryptosporidiosis caused by C. meleagridis has been reported [60].

In mainland Spain, previous studies in wildlife have demonstrated the presence of $C$. muris in rodents [61]. In different studies carried out worldwide, $C$. muris was reported in many rodent species $[23,46,49,62]$, and also in humans [61, 63-66], bilbies [67], birds [68] and other mammals [45, 49, 51, 69-72]. Moreover, C. muris has been reported in children and HIV-positive individuals from developing countries; however, healthy adults are also susceptible to infection [73].

Cryptosporidium sp. rat genotype I and II/III were also detected in the Canary Islands. As Zahedi et al. [74] have described in their review, these genotypes are hostadapted being cited only in rats. In the present study, this host specificity was also observed. Our phylogenetic analysis was not able to distinguish between genotypes II and III, probably due to genetic similarity between these genotypes at the $18 \mathrm{~S}$ locus, as previously published $\mathrm{Ng}$ Hubling et al. [62].

Rat genotype I was identified in brown rats in China and Japan, in Boa constrictor in the USA and rats in the Philippines, and also in environmental samples such as wastewater in China and the UK, among others $[18,62$, 75-77]. Rat genotype II has been previously reported in Asian house rats in China [78], wild black rats in northern Australia [79], Asian house rats and brown rats in the Philippines [62], and has also been found in sheep in Australia [80], among others. In the case of Rat genotype III, previous epidemiological studies highlight it as the most frequent genotype in rats [19]. In addition to rats, mice and cats have also been reported infected with Cryptosporidium sp. rat genotype III [62, 78, 79, 81].

The results obtained in our study suggest that Cryptosporidium sp. 1 may correspond to one unnamed Cryptosporidium genotype isolated from an environmental sample in Aragon (north-eastern Spain) and another unnamed genotype isolated from a storm event water sample from New York $[82,83]$. It was not possible to identify to the species level Cryptosporidium sp. 2. However, the results obtained in our study seem to indicate that this isolate is more related to C. microti, C. suis and C. occultus; therefore, more studies are 
required to confirm the identity of this isolate. This finding may indicate the presence in the Canary Islands of a new species not previously described; however, more studies are required to confirm this hypothesis.

The results obtained in this study reflect a wide distribution of Cryptosporidium spp. in the Canary Islands. This work is of great interest since it constitutes the first finding in this archipelago of three zoonotic species, C. tyzzeri, C. meleagridis and C. muris. Most of the positive samples were found in Tenerife, being spread throughout the island including rural and metropolitan areas. The presence of zoonotic species could imply a risk of zoonotic transmission to humans.

\section{Conclusions}

This study contributes to the knowledge of the biodiversity and distribution of Cryptosporidium species in wild rodents from the Canary Islands. Seven Cryptosporidium species/genotypes were identified, including a possible new species, demonstrating a high diversity of these protozoans in these islands. Also, host specificity previously described was observed for rat genotypes. This is the first detection of the zoonotic species $C$. tyzzeri, $C$. muris and C. meleagridis in the Canary Islands, $C$. meleagridis being the first report in $R$. rattus, as well as of Cryptosporidium sp. rat genotype I and II/III in this archipelago. Cryptosporidium spp. were found with wide distribution in wild rodents in the Canary Islands, including rural and metropolitan areas. Given the interesting results obtained in this study, further analysis in unsampled islands is required in order to better understand the epidemiology of Cryptosporidium spp. across the Canary Archipelago.

\section{Abbreviations}

SEGAl: Servicios Generales de Apoyo a la Investigación de la Universidad de La laguna; MEGA: Molecular Evolutionary Genetics Analysis; BLAST: Basic Local Alignment Search Tool.

\section{Acknowledgements}

We thank the Cabildos that allowed the capture of the animals, and all the staff who contributed to the sample collection.

\section{Authors' contributions}

$K G L$ has performed the experiments, formal analysis, data curation, wrote the manuscript and designed the figures. AMA has contributed to the interpretation of the results and drafted or provided critical revision of the manuscript. PF has contributed substantially to the conception and design of the study, project administration and funding acquisition, designed and supervised experiments and drafted or provided critical revision of the manuscript. All authors read and approved the final manuscript.

\section{Funding}

The study was supported through Fundacion CajaCanarias 2015BIO20 project; ProlD2017010092 project (Proyectos I + D de la Consejeria de Economía, Industria, Comercio y Conocimiento de la Comunidad Autónoma de Canarias and FEDER 2014-2020); Ministerio de Ciencia, Innovación y Universidades of Spain, Universidad de La Laguna, Grant No. 2020/0000528.
Grant RD16/0027/0001, RICET, Spanish Ministry of Science, Innovation and Universities and FEDER. AMA was supported by a Grant from Fundacion LaCaixa (2015BIO20).

\section{Availability of data and materials}

Data supporting the conclusions of this article are included within the article. The newly generated sequences were deposited in the GenBank database under the accession numbers MN599007-MN599026 and MN783636MN783642. The raw datasets analyzed by the authors during the present study are available from the corresponding author upon reasonable request.

\section{Ethics approval and consent to participate}

Animal trapping and use approved in accordance with the Law 42/2007, Law 151/2001 and RD 630/2013, with the expedient numbers A/EST-030/2016, AFF115/16, EEI-007/2019, MRR/rsh and ADL/mjb.

\section{Consent for publication}

Not applicable.

\section{Competing interests}

The authors declare that they have no competing interests.

\section{Author details}

${ }^{1}$ Instituto Universitario de Enfermedades Tropicales y Salud Pública de Canarias, Universidad de La Laguna, San Cristobal de La Laguna, Canary Islands, Spain. ${ }^{2}$ Departament Obstetricia y Ginecología, Pediatría, Medicina Preventiva y Salud Pública, Toxicología, Medicina Legal y Forense y Parasitología, Universidad de La Laguna, San Cristobal de La Laguna, Canary Islands, Spain.

Received: 13 May 2020 Accepted: 30 August 2020

Published online: 04 September 2020

\section{References}

1. Hunter PR, Thompson RA. The zoonotic transmission of Giardia and Cryptosporidium. Int J Parasitol. 2005;35:1181-90.

2. Ryan U, Zahedi A, Paparini A. Cryptosporidium in humans and animals - a one health approach to prophylaxis. Parasite Immunol. 2016;38:535-47.

3. Rosado-García FM, Guerrero-Flórez M, Karanis G, Hinojosa MDC, Karanis P. Water-borne protozoa parasites: the Latin American perspective. Int J Hyg Environ Health. 2017;220:783-98.

4. Pumipuntu N, Piratae S. Cryptosporidiosis: a zoonotic disease concern. Vet World. 2018;11:681-6.

5. Khan A, Shaik JS, Grigg ME. Genomics and molecular epidemiology of Cryptosporidium species. Acta Trop. 2018;184:1-14.

6. Ryan U, Hijjawi N, Xiao L. Foodborne cryptosporidiosis. Int J Parasitol. 2018;48:1-12.

7. Bouzid M, Hunter PR, Chalmers RM, Tyler KM. Cryptosporidium pathogenicity and virulence. Clin Microbiol Rev. 2013;26:115-34.

8. Checkley W, White AC Jr, Jaganath D, Arrowood MJ, Chalmers RM Chen $X$, et al. A review of the global burden, novel diagnostics, therapeutics, and vaccine targets for Cryptosporidium. Lancet Infect Dis. 2015; 15:85-94

9. Xiao L. Molecular epidemiology of cryptosporidiosis: an update. Exp Parasitol. 2010;124:80-9.

10. Ryan U, Xiao L. Taxonomy and molecular taxonomy. In: Cacciò SM, Widmer G, editors. Cryptosporidium: parasite and disease. Vienna: Springer; 2014. p. 3-41.

11. Cacciò S, Chalmers R. Human cryptosporidiosis in Europe. Clin Microbiol Infect. 2016;22:471-80.

12. Feng Y, Ryan UM, Xiao L. Genetic diversity and population structure of Cryptosporidium. Trends Parasitol. 2018;34:997-1011.

13. Holubová N, Zikmundová V, Limpouchová Z, Sak B, Konečný R, Hlásková L, et al. Cryptosporidium proventriculi sp. n. (Apicomplexa: Cryptosporidiidae) in Psittaciformes birds. Eur J Protistol. 2019;69:70-87.

14. Li F, Zhang Z, Hu S, Zhao W, Zhao J, Kvác M, et al. Common occurrence of divergent Cryptosporidium species and Cryptosporidium parvum 
subtypes in farmed bamboo rats (Rhizomys sinensis). Parasit Vectors. 2020;13:149.

15. Xiao L, Feng Y. Molecular epidemiologic tools for waterborne pathogens Cryptosporidium spp. and Giardia duodenalis. Food Waterborne Parasitol. 2017:8:14-32.

16. Meerburg BG, Singleton GR, Kijlstra A. Rodent-borne diseases and their risks for public health. Crit Rev Microbiol. 2009;35:221-70

17. Zhao Y, Cheng P, Gong M, Hou B. Summary of mouse-spread diseases and measures to control them. Zhongguo Bingyuan Shengwuxue Zazhi. 2010;5:378-80.

18. Zhao W, Wang J, Ren G, Yang Z, Yang F, Zhang W, et al. Molecular characterizations of Cryptosporidium spp. and Enterocytozoon bieneusi in brown rats (Rattus norvegicus) from Heilongjiang Province, China. Parasit Vectors. 2018;11:313.

19. Koehler AV, Wang T, Haydon SR, Gasser RB. Cryptosporidium viatorum from the native Australian swamp rat Rattus lutreolus-an emerging zoonotic pathogen? Int J Parasitol Parasites Wildl. 2018;7:18-26.

20. Zhang X, Jian Y, Li X, Ma L, Karanis G, Karanis P. The first report of Cryptosporidium spp. in Microtus fuscus (Qinghai vole) and Ochotona curzoniae (wild plateau pika) in the Qinghai-Tibetan Plateau area, China. Parasitol Res. 2018;117:1401-7.

21. Horčičková M, Čondlová Š, Holubová N, Sak B, Květoňová D, Hlásková L, et al. Diversity of Cryptosporidium in common voles and description of Cryptosporidium alticolis sp. n. and Cryptosporidium microti sp. n. (Apicomplexa: Cryptosporidiidae). Parasitology. 2019;146:220-33.

22. Čondlová Š, Horčičková M, Sak B, Květoňová D, Hlásková L, Konečný R, et al. Cryptosporidium apodemi sp. n. and Cryptosporidium ditrichi sp. n. (Apicomplexa: Cryptosporidiidae) in Apodemus spp. Eur J Protistol. 2018;63:1-12.

23. Čondlová Š, Horčičková M, Havrdová N, Sak B, Hlásková L, Perec-Matysiak A, et al. Diversity of Cryptosporidium spp. in Apodemus spp. in Europe. Eur J Protistol. 2019;69:1-13.

24. Beser J, Bujila I, Wittesjö B, Lebbad M. From mice to men: three cases of human infection with Cryptosporidium ditrichi. Infect Genet Evol. 2020;78:104120.

25. Howald G, Donlan CJ, Galvan JP, Russell JC, Parkes J, Samaniego A, et al. Invasive rodent eradication on islands. Conserv Biol. 2007;21:1258-68.

26. Foronda P, Del Castillo A, Abreu N, Figueruelo E, Piñero J, Casanova J. Parasitic helminths of the wild rabbit, Oryctolagus cuniculus, in different bioclimatic zones in Tenerife, Canary Islands. J Helminthol. 2003;77:305-9.

27. Foronda P, López-González M, Miquel J, Torres J, Segovia M, Abreu-Acosta $\mathrm{N}$, et al. Finding of Parastrongylus cantonensis (chen, 1935) in Rattus rattus in Tenerife, Canary Islands (Spain). Acta Trop. 2010;114:123-7.

28. Abreu-Acosta N, Quispe M, Foronda-Rodríguez P, Alcoba-Florez J, Lorenzo-Morales J, Ortega-Rivas A, et al. Cryptosporidium in patients with diarrhoea, on Tenerife, Canary Islands, Spain. Ann Trop Med Parasit. 2007;101:539-45.

29. Abreu-Acosta N, Martín-Delgado M, Ortega Rivas A, del Castillo Remiro A, Aguiar González E, Valladares Hernández B. Presencia de Giardia lamblia y Cryptosporidium sp. en aguas residuales depuradas reutilizadas para riego agrícola en la isla de Tenerife, España. Efectos del transporte a larga distancia sobre la calidad del agua reutilizada. Rev Salud Ambient. 2002;2:2-7.

30. Abreu-Acosta N, Foronda-Rodríguez P, López M, Valladares B. Occurrence of Cryptosporidium hominis in pigeons (Columba livia). Acta Parasitol. 2009;54:1-5.

31. Abreu-Acosta N, Vera L. Occurrence and removal of parasites, enteric bacteria and faecal contamination indicators in wastewater natural reclamation systems in Tenerife, Canary Islands. Spain. Ecol Eng. 2011;37:496-503.

32. Rodriguez F, Oros J, Rodriguez J, Gonzalez J, Castro P, Fernandez A. Intestinal cryptosporidiosis in pigeons (Columba livia). Avian Dis. 1997;41:748-50.

33. Feliu C, López M, Gómez MS, Torres J, Sánchez S, Miquel J, et al. Parasite fauna of rodents (Murinae) from El Hierro (Canary Islands, Spain): a multidisciplinary approach. Acta Parasitol. 2012;57:171-8.

34. Ritchie LS. An ether sedimentation technique for routine stool examinations. Bull US Army Med Dep. 1948;8:326-30.

35. Young KH, Bullock SL, Melvin DM, Spruill CL. Ethyl acetate as a substitute for diethyl ether in the formalin-ether sedimentation technique. J Clin Microbiol. 1979;10:852-3.
36. Zhao GH, Ren WX, Gao M, Bian QQ, Hu B, Cong MM, et al. Genotyping Cryptosporidium andersoni in cattle in Shaanxi Province, northwestern China. PLoS One. 2013;8:e60112.

37. Zhang X, Tan Q, Zhou D, Ni X, Liu G, Yang Y, et al. Prevalence and molecular characterization of Cryptosporidium spp. in dairy cattle, northwest China. Parasitol Res. 2015;114:2781-7.

38. Kumar S, Stecher G, Li M, Knyaz C, Tamura K. MEGA X: Molecular Evolutionary Genetics Analysis across computing platforms. Mol Biol Evol. 2018;35:1547-9.

39. Saitou N, Nei M. The neighbor-joining method: a new method for reconstructing phylogenetic trees. Mol Biol Evol. 1987;4:406-25.

40. Jones KE, Patel NG, Levy MA, Storeygard A, Balk D, Gittleman JL, et al. Global trends in emerging infectious diseases. Nature. 2008;451:990-3.

41. Jones BA, Grace D, Kock R, Alonso S, Rushton J, Said MY, et al. Zoonosis emergence linked to agricultural intensification and environmental change. Proc Natl Acad Sci USA. 2013;110:8399-404.

42. Savioli L, Smith H, Thompson A. Giardia and Cryptosporidium join the 'neglected diseases initiative.' Trends Parasitol. 2006;22:203-8.

43. Perec-Matysiak A, Bunkowska-Gawlik K, Zalesny G, Hildebrand J. Small rodents as reservoirs of Cryptosporidium spp. and Giardia spp. in southwestern Poland. Ann Agric Environ Med. 2015;22:1-5.

44. Song J, Kim CY, Chang SN, Abdelkader TS, Han J, Kim TH, et al. Detection and molecular characterization of Cryptosporidium spp. from wild rodents and insectivores in South Korea. Korean J Parasitol. 2015;53:737-43.

45. Feng Y. Cryptosporidium in wild placental mammals. Exp Parasitol. 2010;124:128-37.

46. Zhao W, Zhou H, Huang Y, Xu L, Rao L, Wang S, et al. Cryptosporidium spp. in wild rats (Rattus spp) from the Hainan Province, China: molecular detection, species/genotype identification and implications for public health. Int J Parasitol Parasites Wildl. 2019;9:317-21.

47. Ren X, Zhao J, Zhang L, Ning C, Jian F, Wang R, et al. Cryptosporidium tyzzeri n sp (Apicomplexa: Cryptosporidiidae) in domestic mice (Mus musculus). Exp Parasitol. 2012;130:274-81.

48. Karanis P, Plutzer J, Halim NA, Igori K, Nagasawa H, Ongerth J, et al. Molecular characterization of Cryptosporidium from animal sources in Qinghai Province of China. Parasitol Res. 2007;101:1575.

49. Kváč M, Kestránová M, Květoňová D, Kotková M, Ortega Y, McEvoy J, et al. Cryptosporidium tyzzeri and Cryptosporidium muris originated from wild West-European house mice (Mus musculus domesticus) and East-European house mice (Mus musculus musculus) are non-infectious for pigs. Exp Parasitol. 2012;131:107-10.

50. Kvác M, McEvoy J, Stenger B, Clark M. Cryptosporidiosis in other vertebrates. In: Cacciò SM, Widmer G, editors. Cryptosporidium: parasite and disease. Vienna: Springer; 2014. p. 237-323.

51. Wagnerová P, Sak B, McEvoy J, Rost M, Matysiak AP, Ježková J, et al. Genetic diversity of Cryptosporidium spp. including novel identification of the Cryptosporidium muris and Cryptosporidium tyzzeri in horses in the Czech Republic and Poland. Parasitol Res. 2015;114:1619-24.

52. Rašková V, Kvetonova D, Sak B, McEvoy J, Edwinson A, Stenger B, et al. Human cryptosporidiosis caused by Cryptosporidium tyzzeri and $C$. parvum isolates presumably transmitted from wild mice. J Clin Microbiol. 2013;51:360-2.

53. Kimura A, Edagawa A, Okada K, Takimoto A, Yonesho S, Karanis P. Detection and genotyping of Cryptosporidium from brown rats (Rattus norvegicus) captured in an urban area of Japan. Parasitol Res. 2007;100:1417-20.

54. Feng Y, Alderisio KA, Yang W, Blancero LA, Kuhne WG, Nadareski CA, et al. Cryptosporidium genotypes in wildlife from a new york watershed. Appl Environ Microbiol. 2007;73:6475-83.

55. Tan TK, Low VL, Ng WH, Ibrahim J, Wang D, Tan CH, et al. Occurrence of zoonotic Cryptosporidium and Giardia duodenalis species/genotypes in urban rodents. Parasitol Int. 2019;69:110-3.

56. Stensvold CR, Beser J, Axen C, Lebbad M. High applicability of a novel method for gp60-based subtyping of Cryptosporidium meleagridis. J Clin Microbiol. 2014;52:2311-9.

57. Gatei W, Suputtamongkol Y, Waywa D, Ashford RW, Bailey JW, Greensill J, et al. Zoonotic species of Cryptosporidium are as prevalent as the anthroponotic in HIV-infected patients in Thailand. Ann Trop Med Parasitol. 2002;96:797-802.

58. Cama VA, Bern C, Roberts J, Cabrera L, Sterling CR, Ortega Y, et al. Cryptosporidium species and subtypes and clinical manifestations in children. Peru. Emerg Infect Dis. 2008;14:1567-74. 
59. Silverlås C, Mattsson JG, Insulander M, Lebbad M. Zoonotic transmission of Cryptosporidium meleagridis on an organic Swedish farm. Int J Parasitol. 2012:42:963-7.

60. Llorente MT, Clavel A, Goñi MP, Varea M, Seral C, Becerril R, et al. Genetic characterization of Cryptosporidium species from humans in Spain. Parasitol Int. 2007;56:201-5.

61. Torres J, Gracenea M, Gómez MS, Arrizabalaga A, González-Moreno O. The occurrence of Cryptosporidium parvum and C muris in wild rodents and insectivores in Spain. Vet Parasitol. 2000:92:253-60.

62. Ng-Hublin JS, Singleton GR, Ryan U. Molecular characterization of Cryptosporidium spp. from wild rats and mice from rural communities in the Philippines. Infect Genet Evol. 2013;16:5-12.

63. Guyot K, Follet-Dumoulin A, Lelievre E, Sarfati C, Rabodonirina M, Nevez $\mathrm{G}$, et al. Molecular characterization of Cryptosporidium isolates obtained from humans in France. J Clin Microbiol. 2001;39:3472-80.

64. Palmer CJ, Xiao L, Terashima A, Guerra H, Gotuzzo E, Saldias G, et al. Cryptosporidium muris, a rodent pathogen, recovered from a human in Peru. Emerg Infect Dis. 2003;9:1174-6.

65. Gatei W, Wamae CN, Mbae C, Waruru A, Mulinge E, Waithera T, et al. Cryptosporidiosis: prevalence, genotype analysis, and symptoms associated with infections in children in Kenya. Am J Trop Med Hyg. 2006;75:78-82.

66. Muthusamy D, Rao SS, Ramani S, Monica B, Banerjee I, Abraham OC, et al. Multilocus genotyping of Cryptosporidium sp isolates from human immunodeficiency virus-infected individuals in South India. J Clin Microbiol. 2006;44:632-4.

67. Warren K, Swan R, Morgan-Ryan U, Friend J, Elliot A. Cryptosporidium muris infection in bilbies (Macrotis lagotis). Aust Vet J. 2003;81:739-41.

68. Ng J, Pavlasek I, Ryan U. Identification of novel Cryptosporidium genotypes from avian hosts. Appl Environ Microbiol. 2006;72:7548-53.

69. Lupo PJ, Langer-Curry RC, Robinson M, Okhuysen PC, Chappell CL. Cryptosporidium muris in a Texas canine population. Am J Trop Med Hyg. 2008;78:917-21.

70. Kváč M, Hanzlíková D, Sak B, Květoňová D. Prevalence and age-related infection of Cryptosporidium suis, C muris and Cryptosporidium pig genotype II in pigs on a farm complex in the Czech Republic. Vet Parasitol. 2009;160:319-22.

71. Kodádková A, Kvác M, Ditrich O, Sak B, Xiao L. Cryptosporidium muris in a reticulated giraffe (Giraffa camelopardalis reticulata). J Parasitol. 2010;96:211-2.

72. Němejc K, Sak B, Květoňová D, Kernerová N, Rost M, Cama VA, et al. Occurrence of Cryptosporidium suis and Cryptosporidium scrofarum on commercial swine farms in the Czech Republic and its associations with age and husbandry practices. Parasitol Res. 2013;112:1143-54.
73. Chappell CL, Okhuysen PC, Langer-Curry RC, Lupo PJ, Widmer G, Tzipori S. Cryptosporidium muris: infectivity and illness in healthy adult volunteers. Am J Trop Med Hyg. 2015;92:50-5.

74. Zahedi A, Paparini A, Jian F, Robertson I, Ryan U. Public health significance of zoonotic Cryptosporidium species in wildlife: critical insights into better drinking water management. Int J Parasitol Parasites Wildl. 2016;5:88-109.

75. Xiao L, Ryan UM, Graczyk TK, Limor J, Li L, Kombert M, et al. Genetic diversity of Cryptosporidium spp. in captive reptiles. Appl Environ Microbiol. 2004;70:891-9.

76. Feng Y, Li N, Duan L, Xiao L. Cryptosporidium genotype and subtype distribution in raw wastewater in Shanghai, China: evidence for possible unique Cryptosporidium hominis transmission. J Clin Microbiol. 2009;47:153-7.

77. Chalmers RM, Robinson G, Elwin K, Hadfield SJ, Thomas E, Watkins J, et al. Detection of Cryptosporidium species and sources of contamination with Cryptosporidium hominis during a waterborne outbreak in north west Wales. J Water Health. 2010;8:311-25.

78. Lv C, Zhang L, Wang R, Jian F, Zhang S, Ning C, et al. Cryptosporidium spp. in wild, laboratory, and pet rodents in china: prevalence and molecular characterization. Appl Environ Microbiol. 2009;75:7692-9.

79. Paparini A, Jackson B, Ward S, Young S, Ryan UM. Multiple Cryptosporidium genotypes detected in wild black rats (Rattus rattus) from northern Australia. Exp Parasitol. 2012;131:404-12.

80. Ryan UM, Bath C, Robertson I, Read C, Elliot A, McInnes L, et al. Sheep may not be an important zoonotic reservoir for Cryptosporidium and Giardia parasites. Appl Environ Microbiol. 2005;71:4992-7.

81. Yang R, Ying JL, Monis P, Ryan U. Molecular characterization of Cryptosporidium and Giardia in cats (Felis catus) in western Australia. Exp Parasitol. 2015;155:13-8.

82. Jiang J, Alderisio KA, Xiao L. Distribution of Cryptosporidium genotypes in storm event water samples from three watersheds in New York. Appl Environ Microbiol. 2005;71:4446-54.

83. Ramo A, Del Cacho E, Sánchez-Acedo C, Quílez J. Occurrence and genetic diversity of Cryptosporidium and Giardia in urban wastewater treatment plants in north-eastern Spain. Sci Total Environ. 2017;598:628-38.

\section{Publisher's Note}

Springer Nature remains neutral with regard to jurisdictional claims in published maps and institutional affiliations.
Ready to submit your research? Choose BMC and benefit from:

- fast, convenient online submission

- thorough peer review by experienced researchers in your field

- rapid publication on acceptance

- support for research data, including large and complex data types

- gold Open Access which fosters wider collaboration and increased citations

- maximum visibility for your research: over $100 \mathrm{M}$ website views per year

At BMC, research is always in progress.

Learn more biomedcentral.com/submissions 